\title{
“Why did I get a C?”: Communicating Student Performance Using Standards-Based Grading
}

\author{
Michael H. Scarlett, PhD \\ Associate Professor, Education Department \\ Augustana College
}

Standards-based grading, an alternative form of grading in which a student's achievement is based on their performance on a clearly defined set of standards rather than on their performance on tests and assignments, is commonplace in K-12 education but has been slow to catch on in higher education. This article presents an example of how standards-based grading was implemented in two sections of an undergraduate course on assessment to add clarity to the meaning of students' grades. The author reflects on lessons learned from implementation including the benefits and challenges posed by adopting the practice.

"How many points is this worth?" "What do I need to do to get an 'A'?" "Do you offer extra credit?" These are the types of questions I often get from students when we talk about their grades. I generally respond by discussing the weight of different assignments in comparison to tests and projects, the impact of turning assignments in late, the amount of material to be covered on tests, and, almost invariably the admonition, " $t$ 's in the syllabus." Rarely it seems do these conversations focus on student learning. In fact, grades often seem to impede rather than facilitate communication.

To address the confusion that often surrounds the awarding of grades, I implemented an approach that is commonplace in K-12 schools but almost completely absent from higher education called standards-based grading. Standards-based grading is a practice that bases students' grades on their performance on a set of clearly defined learning objectives rather than the completion of assignments and tests or the accumulation of points (Brookhart, 2009; Guskey \& Bailey, 2010). With the system of standards-based grading I implemented, students' grades were calculated by averaging scores they received on rubrics indicating a level of mastery of course objectives. I derived the rubric scores using evidence from tests, quizzes, projects, etc. instead of just adding up points for correct answers. At the end of the course I developed a standards-based report card that clearly showed my students exactly which learning objectives they had mastered and which ones they had not.

What I discovered was that implementing standards-based grading involved much more than a simple cosmetic redesign of my grade book. By aligning my grade book with specific standards and by basing the students' grade on their performance in relation to these standards, the standards-based grading approach caused me to reconceptualize the relationship between assessment, curriculum, and instruction in significant ways. As a result, I had much more substantive conversations with students, focusing on learning rather than policies, effort, or the number of points for an assignment. Most importantly, I felt like the grade I awarded to students at the end of the term much more accurately represented their level of understanding than when my grades were based solely on the number of points students earned. In short, my experience implementing standards-based grading was truly transformational. The 
purpose of this article is to describe a rationale and a process for implementing standards-based grading and to reflect on the benefits and challenges of implementation.

\section{Background on Standards-Based Grading}

To understand standards-based grading it is helpful to understand how it is different from traditional grading practices. In higher education, and in most secondary schools, a student's grade is determined by their performance on a variety of assessments, such as tests, quizzes, and projects. It is common for each assessment to be worth a certain number of points, with assessments that are deemed more significant being worth more points or a greater percentage of the student's grade. Assessments generally address multiple learning goals, sometimes identified on a rubric in the case of a project, or, in the case of a test the learning goals are reflected in the questions, but are often not explicitly communicated to the student (i.e., the final exam will cover all the material addressed since the midterm). In contrast, in a standards-based approach students receive a score for each learning goal or target addressed in the course. The score for each standard is determined by a student's performance on assessment items (test questions, performance assessments, etc.) carefully aligned with the learning targets or goals. For example, my students take three tests during the term. Each test is made up of approximately 20 open-ended questions, and each question is aligned with a learning target with multiple test items aligned to a specific standard. When I grade the tests, I score each item on a scale based on their level of understanding, and then I give a standards-based score that is an average score of the items that addressed that standard. When students get their tests back they can see not only how well they did on each item, but also how well they did on each of the standards. Similarly, students complete several projects and -receive scores on a rubric that is aligned with course learning goals (for a summary of key differences between standards-based grading and traditional grading practices, see Appendix A, and see Appendix B for a sample standards-based grade report).

Standards-based grading is not a new practice in K-12 education. Beginning in the 1990's, the curriculum of elementary and secondary schools became increasingly standards-based. With the passage of No Child Left Behind in 2001, an accountability system was established to monitor the educational progress of students using standardized tests. The pressure to prepare students for standardized testing caused many in education to question the relationship between students' performance in the classroom, represented by their grades, with their performance on standardized tests. Presumably, a student who can get good grades in a math class should do well on standardized tests in the same subject. Now that most states adopted the Common Core State Standards in math and English/language arts the alignment between curriculum, instruction, and assessment is likely to be ever more heavily scrutinized (Welsh, D'Agostino, \& Kaniskan, 2013). Anybody who has seen a report card for an elementary student recently has probably noted how they no longer report a student's grade in single subject areas, such as math or science; instead they report the student's progress on specific skills or standards. 
To make grades a more accurate reflection of what students know and can do in relation to standards, standards-based grading is based on several core principles. First, a grade should represent the degree to which a student has demonstrated mastery of a clearly defined set of standards (Brookhart, 2009; Marzano, 2000; Popham, 2011; Wiggins, 1998) rather than a norm-referenced or relative approach in which students are compared to other students. Second, performance in relation to standards should be defined using clearly articulated descriptors on a scale of four or five levels rather than with a percentage system based on the accumulation of a number of points (Guskey, 2011). Third, factors that influence a grade, but are not directly related to student mastery of a standard, should be considered separately for grading purposes (Guskey, 2011). Such factors include lateness, effort, attendance, and the use of extra credit to "boost" a grade. These factors only serve to confuse the true performance of the student. Fourth, a grade should reflect how much a student has learned and not when they learned it, meaning, the most recent and/or consistent evidence of a student's understanding should be considered over a simple averaging of performance on tests and assignments over the course of a year or semester. Finally, and related to the last principle, students should not be

...reassessment provides teachers with opportunities to use grades to facilitate meaningful communication with students.

penalized for practice, meaning, not all assignments should be factored into a student's grade (Fisher, Frey, \& Pumpian, 2011). Homework, practice problems, or other types of formative assessment should be used for feedback but not to determine a final grade because they reflect a students' developing understanding and not their final understanding, which should be measured using summative assessments.

In addition to these core principles, standards-based grading is often connected to mastery learning (Guskey, 1980). The underlying assumption behind mastery learning is that all students should be provided with multiple opportunities to demonstrate their understanding of a standard to achieve proficiency. Grades in this approach are used to help identify students' strengths and weaknesses to foster growth rather than simply to identify talent (Guskey, 2011). Allowing opportunities for reassessment provides teachers with opportunities to use grades to facilitate meaningful communication with students about their specific strengths and weaknesses.

\section{Review of Literature}

While the research supporting the use of standards-based grading is lacking, there are several studies that suggest traditional grading practices are flawed. For example, in two famous early studies by Starch and Elliot $(1912,1913)$ on the subjectivity of grading they discovered a wide range of scores awarded by teachers grading the same assignment, even when it involved subjects like geometry. Brimi (2011) replicated one of these early studies and discovered almost identical results, even after teachers had received 20 hours of training on assessment. Another problem is that the meaning of a grade is often difficult to ascertain because it conflates too many factors-lateness, effort, neatness, for example-often unrelated to learning or impossible to measure (Gordon \& Fay, 2010). The well-documented rise in grade 
inflation, too, suggests that there is good reason to be skeptical of the meaning of grades as a true measure of a students' understanding (Rojstaczer \& Healy, 2012; Seligman, 2002). Brookhart (1994) discovered in her research on teachers' grading practices a lack of congruence between best practices in the field of assessment and how teachers graded their students. In other words, many teachers are simply not well-educated when it comes to issues of assessment and grading. This is particularly clear in the emphasis teachers place on grades as a reward for students' work, rather than a level of achievement (Brookhart, 1993, p. 139). These are just a few of the reasons why experts in assessment advocate for standards-based grading as an alternative to traditional grading.

The studies done in K-12 education on the practice of standards-based grading suggest that it can improve student learning and may increase student motivation. A large-scale study in the Denver area, for example, demonstrated a higher correlation between grades and standardized test scores in schools with standards-based grading versus those without. The scores on standardized tests in schools with standards-based grading were higher than in schools without (Haptonstall, 2010). In the Omaha Public Schools as well, the number of students failing classes decreased significantly when a standards-based approach to grading was implemented (Proulx, Spencer-May, \& Westerberg, 2012). Also, in a study by Fisher et al. (2011) a school in San Diego that implemented several components of standards-based grading saw their performance on state tests increase as well as students' GPAs. Despite these positive findings, very little research has been done in higher education related to the use of standards-based grading.

The few studies that do exist on the use of standards-based grading in colleges or universities suggest that grade reform is possible in higher education, and the experiences of both the professors and students involved in the studies were generally positive. Beatty (2013), for example, documented his experience implementing standards-based grading in two semesters of university physics. He discovered that many, but not all, students liked the standards-based approach; however, the logistics of successful implementation are significant and challenging. Rundquist (2011) also reported a similarly positive experience implementing standards-based grading in an upper level physics course. Finally, Kalnin (2014) implemented proficiency-based grading in one instructional unit in a course on assessment and found that the process gave her a deeper appreciation of the challenges of "practicing what we preach," and it deepened her students' assessment literacy. To date, these appear to be the only studies specifically on the use of standards-based grading in college or university settings; however, given currents trends in K-12 education it appears likely that standards-based grading will continue to grow in use in colleges and universities, and the need for a better understanding of the best practices in implementing this approach will only increase.

\section{Context}

The context in which I implemented standards-based grading was a private, selective liberal arts college in the Midwest. The course was Assessing Learning, a required course for all students in the Education program, which includes elementary, 
secondary, and K-12 majors. As the second course in the education sequence, most students take Assessing Learning as sophomores, and they have all either been fully or provisionally admitted into the education program by the time they take the course, meaning most the students have at least a 3.0 GPA and received a minimum of a 22 on the ACT or 1100 on the SAT. The fact that the students were all majors and most have met minimum program requirements means that they, on average, are more highly motivated and capable than the average student on our campus. Also, as majors in education they tend to have a high level of engagement and interest in topics such as grading.

\section{The Process of Implementing the Standards-Based Grading Approach}

To implement the standards-based grading approach I consulted a variety of articles and texts, mainly relating to the context of K-12 education, but also those mentioned above in higher education. Various articles cited below influenced practical considerations, but the overall process came from the course text (Popham, 2011) and the work of Guskey and Bailey (2010) and Marzano (2000). I used Popham's process primarily because I wanted to model what was presented in our course text, and I found that there was a great degree of conceptual similarity between the different approaches, even though Popham refers to the approach as "goal-attainment grading." Guskey and Bailey (2010) and Marzano (2000) provided more in-depth answers to the many practical considerations I needed to make.

\section{Step 1: Clarifying Curricular Aims or Standards}

The first step in implementing the standards-based grading approach is to determine a set of learning targets or objectives that accurately reflect important concepts and skills addressed in the course. I started with ten course goals, which were broad statements of what the teacher candidates need to know and be able do. Using these broad outcomes as a guide I thoroughly reviewed course materials and readings to identify more specific and assessable learning targets reflecting the knowledge and skills I deemed necessary to be literate in classroom assessment practices. Bloom's Taxonomy was useful for ensuring the learning targets represented an appropriate range of cognitive challenge and for ensuring the learning targets were all assessable. Examples of specific learning targets can be found in the sample standards-based report card in Appendix B.

Once I identified an appropriate number of learning targets addressing the essential content and skills, I considered what non-academic behaviors were important for my students to demonstrate. Advocates of standards-based grading argue that non-academic factors such as lateness, effort, attendance, etc., should not be used to determine a standards-based grade (Guskey \& Bailey, 2010); however, Guskey and Bailey (2010) recommend acknowledging the importance of these non-academic factors by separating students' grades into product (mastery of course objectives), process (factors such as attendance), and progress (how much a student has gained from a course). The process goals I deemed most important included attendance, active participation, meeting deadlines, completing assignments (even ungraded ones), and 
the general professional dispositions desirable of an adult working with children (use of appropriate language, communication skills, etc.). See Appendix B for an example of how the process grade was communicated to students using the standards-based report card. A progress grade was not computed because of the challenges of fairly determining the amount of growth attained by each student during the term were simply too great, particularly given an eleven-week trimester.

Another step in the process of clarifying one's curricular aims is to identify the criteria by which you will determine if a student has mastered the aim (Popham, 2011, p. 391). Having an idea of what mastery looks like is an essential step in clarifying for oneself and one's students what the curricular aim is. After reviewing multiple examples of rubrics (Beatty, 2013; Guskey \& Bailey, 2010; Rundquist, 2011), I arrived at a five-point scale to evaluate student learning in relation to my learning targets (see Appendix C).

\section{Step 2: Choosing Standards-Based Assessment Evidence}

Once I identified my learning targets, both product and process related, I reviewed my course assessments - a combination of performance assessments and traditional tests - to make sure I was collecting appropriate evidence of my students' understanding. All my assessment items required constructed responses in which students needed to write out an answer rather than multiple choice or true/false questions. Multiple assessments were helpful for a variety of reasons, some of which will be discussed in the next section, but overall, advocates of the standards-based grading approach suggest that students should have multiple opportunities to demonstrate mastery of course learning targets, and a grade should be based on a sufficient amount of evidence (Marzano \& Heflebower, 2011). I found that I really did not have to significantly change my assessments, but rather the process required me to think about how my assessments were connected to my learning targets and how strong the evidence was I collected.

I also excluded a wide range of assignments I normally would have included in the grade book when calculating the final grade. The types of assignments excluded fall into the category of formative assessments, assignments designed to collect evidence of a student's progress towards meeting standard for feedback and to assist the student in monitoring their own learning (Popham, 2011). Examples of formative assessments not included for grading were daily homework assignments, quizzes, and other in class assignments. While these assessments were critical for me as the professor to know if my students were learning, including them in the final grade would have ultimately punished students for practice (Fisher et al., 2011).

\section{Step 3: Weighting Standards-Based Assessment Evidence}

When considering how to weight the evidence that would be used to determine the final grade, I again considered the basic tenet of the standards-based grading approach that low grades received early in a term should not be averaged with grades received later (Fisher et al., 2011). This means that my grade book was set up so that the time of assessment was taken into account and that the most recent grade a 
student received was the most important grade in determining the final grade. While there are different models and approaches to determine a grade for a single standard (Hooper \& Cowell 2014; Marzano 2000), using the most recent score made sense to me both because it didn't penalize student for low grades early in the term and because it would ostensibly communicate to students that what really matters is how they finish, not how they start. The fact that average scores on my first test tend to be much lower than on later tests suggests to me that students also need to get used to the assessments and the expectations for assessment evidence graded as distinguished, on target, etc.

Another question related to the weighting of evidence is what to do if a student scores lower on a reassessment opportunity. Should the lower, but most recent score be used, should the new score be disregarded, or should the scores be averaged? I decided to average the two most recent scores because I wanted to communicate to students that the fact they had already demonstrated a higher level of understanding was important, but consistency was also important and, if a student had mastered a learning target early in the term with a 4 but forgot what they learned and scored a 1 , then perhaps they really did not reach a level of mastery warranting a score of "distinguished."

Lastly, it was clear to me as I determined the standards to be assessed that not all standards should be weighted equally. Some standards were more important because they reflected a greater level of cognitive complexity or they were more fundamental to the broader course outcomes required by the course and the program. For example, my students' ability to identify different types of assessment bias was important, but their ability to construct their own assessment items that were free from assessment bias was even more important and worthy of more weight in the grade book. The system of weighting used involved a multiplier from 1 to 4 depending on the complexity and significance of the standard being assessed. This system of weighting was useful when communicating with students because it gave them an idea of what knowledge and skills were most significant and why.

\section{Step 4: Arriving at a Final Standards-Based Grade}

The overarching purpose of standards-based grading is to clearly communicate to students a level of performance in relation to a set of standards, and the best way to do this is to use a reporting system that is sufficiently detailed to accomplish this task. Guskey and Bailey (2010) recommend reporting performance on non-academic or process goals separately from product and progress goals so that the ability of the grade to clearly communicate will not be diminished (p. 157). Yet in higher education and in most secondary schools there is a need to award a student a final, omnibus grade. Acknowledging the significance of grades for students to advance in our program and with an understanding of the need to ensure that the grades I awarded students were indeed reflective of their mastery of course standards, I provided students with a grade report that was separated into process and product grades so that I could communicate to them what their grade was based on, but I also calculated a final grade that reflected both academic and non-academic performance. My decision to include the process score in the students' overall grade is a significant departure from the spirit of standards-based grading, but I was concerned that a 
student could receive a good final grade in the course but not demonstrate the types of dispositions we expect of our students, and in my case, future teachers. Accordingly, I wanted the final grade to reflect both mastery of content and professional dispositions.

To do this I decided that to receive an "A," a student should demonstrate an understanding at the distinguished level on a majority of the learning targets and exhibit no non-academic concerns. With this in mind I arrived at a final, omnibus grade, by averaging their performance on the learning targets, using the most recent evidence (or an averaging of the previous two scores if the most recent score was lower) and averaging the scores awarded for non-academic factors (determined through a combination of self, peer, and instructor assessment, depending on the trait). Finally, I multiplied the product score by $.8(80 \%)$ and the process score by $.2(20 \%)$ and combined them to determine the final score, which I then converted to a letter grade using the grade point scale (see Appendix B for a sample grade book). The final grades I awarded were comparable in range and distribution to grades given in nonstandards-based grading courses, but unlike in non-standards-based grading courses, they were based on clearly defined standards of performance.

\section{Reflections on the Process}

My main take-away from implementing standards-based grading and from reviewing the research is that it is an approach with a great deal of value because it encourages healthy reflection on what we teach and how we assess our students. It also fosters communication with our students by making the focus of a grade on student achievement rather than on success on an assessment instrument. The grades students received at the end of the course more accurately reflected a level of understanding of course content than in the past when I based my grades on an accumulation of points. Also, the way I communicated with students about their grades and assessments improved significantly. Rather than discussing low test scores or a failure to complete assignments as the reason for a poor grade, I used a standardsbased "report card" to communicate with students' specific learning targets they still needed to master and the opportunities they would have to demonstrate their understanding of these learning targets. In course evaluations students reported that they clearly understood the relationship between course content, in-class learning activities, and assessments, and that this helped them to focus on learning what was important. These conversations represented a significant, positive shift in the way I talked about grades and assessment with students.

In fact, students' reaction to standards-based grading were mostly very positive. The results from an anonymous post-course survey indicate students liked the clarity of standards-based grading and that it gave them a sense of control over their grade because of the opportunities for re-assessment. On the other hand, some students felt that the standards were set too high or that they were not sure what they needed to do to reach a higher level of mastery. Also, the practice confused some students. I believe this was partly because it was different from what they were used to and partly because I was still learning how to implement the practice. Despite some negative comments, scores on course evaluations were much higher than the average for other courses at the institution, specifically on items related to grading and 
assessment. Overall, the majority of students appreciated the approach and wished other faculty used it in their courses.

The process also required me to think about my assessments differently as each item on a test, for example, was connected to a specific learning target. Reviewing my assessments from this perspective improved them by ensuring that course content was adequately represented. Most importantly, when I graded my tests, I was able to see which learning targets students struggled with and which the majority had mastered. Understanding student and class performance in relation to learning targets then led me to examine my teaching practices and the ways I presented different topics in class. As a result of this reflection, I made several changes to my teaching to better address specific learning targets students struggled with, including using more formative assessments and structuring in-class activities to address specific topics in more depth. I also used item analysis to inform future assessments, making sure to include questions on topics the class overall struggled with to provide them with an opportunity for reassessment.

Providing both individual and group opportunities for reassessment represented another significant improvement afforded by standards-based grading. While not all students took advantage of opportunities to reassess, I believe those who did benefited from the opportunity to review material and to demonstrate their understanding in different ways. In almost all cases reassessment led to higher scores for students, and, because the higher, most recent score was used to determine the final grade, this final grade was a more accurate representation of the students' level of understanding.

Despite my generally positive experience, standards-based grading is not without its pitfalls. Something that I hear quite often from K-12 teachers, and is reflected in my own course surveys, is that standards-based grading is difficult to understand at first because it is different. Another common complaint I hear from K12 and pre-service teachers is that students are not as motivated to complete assignments if they know the grades on the assignments will not count for their grade. The practice of not grading work that is formative, a central component of standardsbased grading, reflects a significant hurdle for teachers or professors wanting to implement this approach. The way I addressed this concern was to include work completion in the process grade, so that a students' grade was impacted if they failed to complete homework assignments. In addition, to participate in class students needed to come prepared with their work complete, which was another graded component of the course. Standards-based grading is also difficult to implement because it requires professors to think about assessment differently. It was definitely more work grading because, rather than just adding up the number right on tests, I was thinking about the level of understanding reflected in their answer compared to a standard of performance.

My main conclusion is that the philosophy and the growing body of research supporting standards-based grading is promising, but the realities of assessing and grading in higher education present professors with challenges of implementing it with fidelity. Issues such as arriving at a final, end-of-course grade that does not take into account non-academic factors, providing multiple opportunities for reassessment, and not grading homework are all elements of standards-based grading that I struggled 
with as I implemented the approach. My review of the three published articles related to the implementation of standards-based grading suggest that the issues I faced are not uncommon; however, the way these issues are addressed varies depending on context. The nature of the course and the methods of assessment will likely determine what standards-based grading will look like in practice.

\section{Recommendations}

While my experience and the reaction of the students was positive overall, more needs to be done to "work out the kinks." The challenges to implementing this approach in a higher education context with fidelity to the basic principles are significant. To be successful multiple iterations are likely to be needed and much more serious, systematic inquiry into the benefits and limitations will be needed.

My first recommendation is that more research needs to do be done to better understand best practices for implementing standards-based grading in higher education. Some of the more obvious areas in need of investigation include: what role does context play in the successful implementation of the standards-based grading approach? In K-12 education standards-based grading has been implemented in a wide variety of contexts, but it seems to run into more resistance in secondary education. Could it be that the content being taught and the course level will determine whether or not standards-based grading can be implemented successfully? It seems to work well in college physics and assessment courses, but what about upper division writing courses or introductory language courses? Is it feasible in large, lecture style courses or will it only be manageable when course enrollment is low?

Another question needing to be researched is how does the standards-based grading influence students' approach to learning and their overall mastery of the course goals? If the standards-based grading approach is meant to improve learning, do we know this is really happening? The work that has already been done is promising because it suggests students view the approach favorably, but the next step needs to be taken particularly when the opportunity to compare student learning in courses with standards-based grading and without standards-based grading is available.

For those interested in implementing standards-based grading, my recommendation is to start by developing a mock grade book representing the elements that you feel are most important to you and that will help to facilitate communication with your students. If a significant reason to adopt standards-based grading is to improve communication, then the tool used to convey this information to students is important. Once you have an idea of what the final product will look like then the process for arriving at the grade report, outlined in the article, will likely make more sense.

The work that has already been done on standards-based grading suggests that it is a worthwhile approach but that it is challenging to implement. In my experience, the challenges are worth the effort because of the clarity standards-based grading brought to my grading process and the improved levels of communication it enabled. Given that standards-based grading is likely to become more commonplace in higher education it behooves us to continue to work out the kinks and to learn from each other. 


\section{References}

Beatty, I. (2013). Standards-based grading in introductory university physics. Journal of the Scholarship of Teaching and Learning, 13(2), 1-22. Retrieved from

http://www.iupui.edu/ josotl

Brimi, H. (2011). Reliability of grading high school work in English. Practical Assessment, Research and Evaluation, 16(17), 1-12. Retrieved from http://pareonline.net/pdf/v16n17.pdf

Brookhart, S. (1993). Teachers' grading practices: Meaning and values. Journal of Educational Measurement, 30(2), 123-142.

Brookhart, S. (1994). Teachers' grading: Practice and theory. Applied Measurement in Education, 7(4), 279-301.

Brookhart, S. (2009). Grading (2nd ed.). New York, NY: Merrill.

Fisher, D., Frey, N., \& Pumpian, I. (2011). No penalties for practice. Educational Leadership, 69(3), 46-51. Retrieved from http://www.ascd.org/publications/educa tional-leadership/nov11/vol69/num03/ abstract.aspx

Gordon, M., \& Fay, C. (2010). The effects of grading and teaching practices on students' perceptions of fairness. College Teaching, 58, 93-98.

Guskey, T. R. (1980). Mastery learning: Applying the theory. Theory into Practice, 19(2), 104-111.

Guskey, T. R. (2011). Five obstacles to grading reform. Educational Leadership, 69(3), 16-21. Retrieved from http://www.ascd.org/publications/educa tional-leadership/nov11/vol69/num/03/ abstract.aspx
Guskey, T. R., \& Bailey, J. (2010). Developing standards-based report cards. Thousand Oaks, CA: Corwin Press.

Haptonstall, K. G. (2010). An analysis of the correlation between standards- based, non-standards-based grading systems and achievement as measured by the Colorado student assessment program (CSAP, Doctorial dissertation). Retrieved from ProQuest Dissertations and Theses. (UMI No. 3397087)

Hooper, J., \& Cowell, R. (2014). Standards-based grading: History adjusted true score. Educational Assessment, 19(1), 58-76.

doi: 10.1080/10627197.2014.869451

Kalnin, J. (2014). Proficiency-based grading: Can we practice what they preach? AILACTE Journal, 11(1), 19-36. Retrieved from

http://www.eric.ed.gov/contentdelivery/ servlet/ERICServlet?accno=EJ1052571

Marzano, R. (2000). Transforming classroom grading. Alexandria, VA: ASCD.

Marzano, R. J., \& Heflebower, T. (2011). Grades that show what students know. Educational Leadership, 69(3), 34-39. Retrieved from

http://www.ascd.org/publications/educa tional-leadership/nov11/vol69/num03/

abstract.aspx

O'Connor, K. (2002). How to grade for learning: Linking grades to standards (2nd ed.). Thousand Oaks, CA: Corwin Press.

Popham, J. (2011). Classroom assessment: What teachers need to know. Boston, MA: Pearson. 
Proulx, C., Spencer-May, K., \& Westerberg, T. (2012). Moving to standards-based grading: Lessons from Omaha. Principal Leadership, 13(4), 30-34. Retrieved from

http://www.principals.org/Default.aspx

?TabId=2043

Rojstaczer, S., \& Healy, C. (2012). Where $A$ is ordinary: The evolution of university and college grading, 19402009. Teachers College Record, 114(7), 1-23. Retrieved from

http://www.tcrecord.org/Content.asp?C ontentId=16473

Rundquist, A. (2011). Standards-based grading with a voice: Listening for students' understanding. In N. S. Rebello, P. V. Englehardt, \& C. Singh, (Eds.). AIP Conference Proceedings, 1413 (pp. 69-72). doi: 10.1063/1.3679996

Seligman, D. (2002, March 18). The grade-inflation swindle. Forbes, 19.

Starch, D., \& Elliott, E. C. (1912). Reliability of the grading of high-school work in English. School Review, 20, 442457. Retrieved from http://www.jstor.org/stable/1076706
Starch, D., \& Elliott, E. C. (1913). Reliability of grading work in mathematics. School Review, 21, 254-259. Retrieved from http://www.jstor.org/stable/1640875

Townsley, M. (2014, November 11). What's the difference between standards-based grading (or reporting) and competency-based education? Retrieved from

http://www.competencyworks.org/anal ysis/what-is-the-difference-between-

standards-based-grading/

Welsh, M., D'Agostino, J., \& Kaniskan, B. (2013). Grading as a reform effort: Do standards-based grades converge with test scores? Educational Measurement: Issues and Practice, 32(2), 26-36.

doi: 10.1111/emip.12009

Wiggins, G. (1998). Educative assessment: Designing assessments to inform and improve student performance. San Francisco, CA: Jossey-Bass Publishers. 


\section{Appendices}

Appendix A

Table A1

Summary of Differences between Traditional Grading and Standards-Based Grading Traditional Grading System

1. Based on assessment methods (quizzes, tests, homework, projects, etc.). grade/entry is given per assessment. One

1. Based on learning goals and performance standards. One grade/entry is given per learning goal.

2. Standards are criterion or 2. Assessments are based on a percentage proficiency-based. Criteria and targets system. Criteria for success may be unclear. are made available to students ahead of time.

3. Use an uncertain mix of assessment, 3. Measures achievement only OR achievement, effort, and behavior to separates achievement from determine the final grade. May use late effort/behavior. No penalties or extra penalties and extra credit. credit given.

4. Everything goes in the grade book regardless of purpose.

5. Include every score, regardless of when it was collected. Assessments record the average - not the best - work.
4. Selected assessments (tests, quizzes, projects, etc.) are used for grading purposes.

5. Emphasize the most recent evidence of learning when grading.

Note. Adapted from How to Grade for Learning: Linking Grades to Standards (2nd ed.), by M. Townsley from K. O'Connor (2002). Copyrighted 2014 by Corwin Press. 
Appendix B

Sample Standards-Based Report Card

\begin{tabular}{|c|c|c|c|c|}
\hline Name: & \multicolumn{4}{|l|}{ Doe, John } \\
\hline Course \#: & \multicolumn{4}{|l|}{ EDUC 330} \\
\hline Section \#: & \multicolumn{4}{|l|}{1} \\
\hline \multicolumn{5}{|c|}{ Product Grade $(80 \%)$} \\
\hline \multirow{8}{*}{ 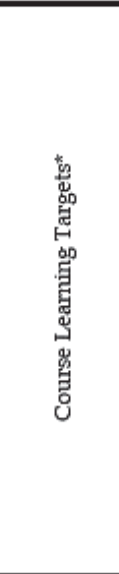 } & The student... & Weight & $\begin{array}{l}\text { Final } \\
\text { Unweighted } \\
\text { Score }\end{array}$ & $\begin{array}{l}\text { Final } \\
\text { Weighted } \\
\text { Score }\end{array}$ \\
\hline & knows how to collect reliability evidence & 1 & 3 & 3 \\
\hline & $\begin{array}{l}\text { can define assessment bias and identify its } \\
\text { different forms }\end{array}$ & 1 & 3 & 3 \\
\hline & $\begin{array}{l}\text { can explain the difference between norm- } \\
\text { referenced and criterion-referenced score } \\
\text { interpretations }\end{array}$ & 1 & 4 & 4 \\
\hline & $\begin{array}{l}\text { can create a performance assessment and identify } \\
\text { its key features }\end{array}$ & 4 & 2 & 8 \\
\hline & $\begin{array}{l}\text { knows the difference between aptitude and } \\
\text { achievement tests and appreciate the appropriate } \\
\text { uses for each }\end{array}$ & 2 & 4 & 8 \\
\hline & $\begin{array}{l}\text { can define formative and summative assessment } \\
\text { and identify the purposes of each }\end{array}$ & 3 & 4 & 12 \\
\hline & $\begin{array}{l}\text { can identify different approaches to grading and } \\
\text { evaluate their relative worth }\end{array}$ & 2 & 3 & 6 \\
\hline & Total Weighted Standards & 14 & $\begin{array}{r}\text { Total } \\
\text { Weighted } \\
\text { Score }\end{array}$ & 44 \\
\hline \multicolumn{4}{|c|}{ Total Weighted Score/Total Weighted Standards } & 3.14 \\
\hline \multicolumn{4}{|c|}{ Average Product Score $\times .8$} & 2.51 \\
\hline
\end{tabular}

\begin{tabular}{|c|c|c|c|c|}
\hline \multicolumn{5}{|c|}{ Process Grade $(20 \%)$} \\
\hline \multirow{5}{*}{ 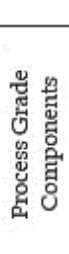 } & & Score & & \\
\hline & Attendance & 3 & & \\
\hline & Participation & 4 & & \\
\hline & Timeliness & 4 & & \\
\hline & Homework Completion & 3 & & \\
\hline & Average & 3.5 & $\begin{array}{l}\text { Avg. Product Scoret } \\
\text { Avg. Process Score }\end{array}$ & 3.21 \\
\hline & Average Process Score $\times .2$ & .7 & Final Grade & B \\
\hline
\end{tabular}

*This is just a sample of the course learning targets upon which the grade was based.

\begin{tabular}{|l|l|l|l|l|l|}
\hline \multicolumn{2}{|l|}{ Grade Scale } & A & $4.0-3.71$ & A- & $3.7-3.5$ \\
\hline B+ & $3.49-3.3$ & B & $3.29-3.0$ & B- & $2.9-2.7$ \\
\hline C+ & $2.69-2.3$ & C & $2.29-2.0$ & C- & $1.99-1.7$ \\
\hline D & $1.7-0$ & \multicolumn{5}{|l}{} \\
\hline
\end{tabular}


Table A2

\section{Appendix C}

Generic scale used to evaluate assessment evidence

\begin{tabular}{ll} 
Level of Performance & Performance Descriptor \\
\hline 4-Distinguished & $\begin{array}{l}\text { Students demonstrates clear, accurate, and advanced } \\
\text { evidence of understanding }\end{array}$ \\
3-Mastery & $\begin{array}{l}\text { Student demonstrates a clear, accurate understanding } \\
\text { 2-Developing }\end{array}$ \\
1-Concern & $\begin{array}{l}\text { Student demonstrates a partial understanding } \\
\text { 0-No evidence }\end{array}$ \\
\hline
\end{tabular}

\section{Appendix D}

Student post-course survey comments

\section{What did you like about standards-based grading, if anything?}

That it reflects what [is] most important; Learning

I like how the intangibles are separate from the overall grade. This makes the student's assignment grade more accurate as to the caliber of his/her performance in mastering the learning targets. It also provides more organization for the teacher because basically everything (assessments, grading, instruction, etc.) revolves around the learning targets he/she puts in place to satisfy standards. This ensures that teachers do not get too carried away with planning only somewhat related lessons because everything has to tie back to the learning targets.

I like how there is something that everyone could achieve and work up to.

I like that standards-based focuses on the mastery of content when giving a grade. Then nothing else would influence the grade and students, parents, and teachers would get a clear understanding of the student's learning.

I liked that we had the opportunity to reassess on certain learning targets that we did not fully master.

I like the reassessment opportunities.

I like that we can do reassessments for our learning targets.

It really shows whether or not you understand the content and where you need to focus your attention if you want to raise your grade. 
I was able to be reassessed. I could see where I went wrong on what topic. I liked how I knew everything that was going to be on the test. I knew exactly what to study. Nothing was a surprise.

It is extremely fair. I like that the standards are communicated with us before hand and we know exactly what we are going to be graded on.

I did like how I was better able to tell what I did know and didn't. It was easier than just a percentage.

I like that learning targets were given to us for every class period, and we knew exactly what was expected for us to know and be assessed on.

I liked how it set out a certain criteria.

The learning targets make it easy to track progress and help students know what to study.

I did enjoy seeing exactly where I was lacking. Being able to see the learning targets and my score on each helped motivate me to reach $4 \mathrm{~s}$ for every target

It follows the course objectives/ learning targets and it measures student mastery of their content

I liked that it showed the level of understanding for each of the standards and that the grade was not given but it had more of an impression that it was being earned.

Only assess[es] the students learning based on the standards being assessed

It most resembled how much I actually learned.

I thought this was an awesome way to grade, especially with reassessment opportunities.

\section{What did you NOT like about standards-based grading, if anything?}

Not understanding my grade for 8 weeks.

I honestly like standards-based grading but I feel like it would be a culture-shock to suddenly implement this in schools. Although people would eventually get used to it, I feel like many students and parents would be initially overwhelmed by the grading format as it would appear on something like PowerSchool. Instead of having the traditional format of exams, homework assignments, participation, etc., there would be actual learning targets with assignments listed under it. Like I said, people would get used to it, but I know that I would be somewhat alarmed if my child's grading format was changed dramatically from the way I was comfortable with. 
I think it would be hard to not consider effort when giving a grade because it is very important in the learning process.

I was sometimes confused about why I got a different level than I expected (for example, a "Target" instead of "Distinguished"), and I didn't feel like this was ever explained to me.

I really enjoyed it a lot. The only thing was that I wasn't used to this type of grading, so it took me a while to adjust to how I can view my performance.

I did not necessarily dislike it, but I could see that some people would dislike how heavily test scores are weighted and that their homework does not count for much.

The teacher controls the standards, so sometimes they are subjective.

I didn't know why I got the score I got and what was the $100 \%$ correct answer ever.

I did not like how on a test if you mastered it the first time, but then is it was to be reassessed and you didn't do as well the second time, then the score was reevaluated and lowered.

It can be too specific - not allowing for creativity or wiggle room.

I did not like how hard it was to gain mastery. I understand it, but it took a lot more work to earn my A than other classes may take.

I do not like the fact that it is often difficult to tell how I did on a particular assignment. For me, I do not think of my courses as being separated into various standard. I think of them as being separated into various assignments. If you tell me I got a $2 / 3$ on this standard, that doesn't mean anything to me. But if you tell me I got an $85 \%$ on the rubric project, I can judge that against how I *thought* I should have done on that project and determine whether I need to put in more effort. In short, I think it's useful for letting students know how they are doing, which as a student is frustrating.

When being reassessed I did not like the averaging of the scores if the 2 nd time the grade was lower.

Michael Scarlett is an assistant professor in the Education Department at Augustana College in Rock Island, IL. He teaches courses on assessment, educational technology, and methods of teaching social studies. His research interests include game-based learning, the history of American Indian education, and standards-based grading. 